Guttmann, L. (England) replied that there were no statistics on ulcers occurring in acute high cervical lesions. It would, of course, be important to investigate these cases in the early stages, but this, as a rule, was not feasible. With regard to treatment, the main measure was the blood transfusion. In one of their cases they had called in the services of a general surgeon and he had indeed rescued the patient. In the case reported by Dollfus and Frankel, the surgeon declined to operate. He was quite right, for the patient was too critically ill and died.

Ross, J. C. (England) said that with regard to the cases of bleeding shortly after a high injury, although they had not yet done so they had in mind to use gastric cooling when such a case arose again. After all, the apparatus was not very complicated, they had it going in Liverpool at present for other cases and it seemed to him particularly suitable for that type of patient.

PAESLACK, V. (Germany) said they had used gastric cooling on such a case, but without any effect, and the patient died 24 hours later.

HARDY, A. G. (England) thought perhaps, as Chairman, he could have the last word. They had had 396 acute admissions in the last Io years, with nine cases of alimentary tract bleeding, two cases of haemorrhagic ulcerative colitis and three deaths in this series of nine.

\title{
CIRCULATORY REFLEXES IN SPINAL MAN
}

\author{
By J. R. Silver, M.B., B.S., M.R.C.P., Ed. \\ National Spinal Injuries Centre, Stoke Mandeville Hospital
}

THE reflex activity that is responsible for changes in muscle blood flow with posture and following the Valsalva manœuvre is believed to arise in low-pressure receptors rather than in arterial baroreceptors (Shepherd, 1963). While it has been established that the efferent side of these reflexes is by the sympathetic nervous system, the afferent side of these reflexes and their central connections are obscure.

Sharpey-Schafer (1956) has pointed out that if such reflex activity can be eliminated, it is much easier to understand the physiology of the circulation, since it is possible to differentiate between changes occurring which are central or reflex in origin and changes occurring that are local or mechanical in origin. It seemed that the study of a group of subjects who had sustained a complete physiological interruption of their spinal cords as a result of trauma above or at the level of the sympathetic outflow could offer a unique opportunity to determine which of these reflexes were spinal in origin, and which required the continuity of the brain stem, spinal cord and sympathetic chain for their elicitation.

The reflexes studied were the changes in the forearm blood flow in response to passive elevation of the legs, the Valsalva manœuvre and heating of the lower part of the body.

Clinical Material. Eight tetraplegic patients and three normal controls were studied. The level of the spinal cord lesion varied between $\mathrm{C} 6$ and $\mathrm{T}_{3}$. In each case complete loss of sensory and motor function as well as loss of control of bladder and bowel function indicated that there was a complete loss of functional continuity of the cord at the appropriate level. Five of the patients were complete lesions above the sympathetic outflow ( $\mathrm{T}_{\mathrm{I}}$ ), the remaining three patients had only 
sparing of light touch in the upper three thoracic dermatomes. They were all male and their ages ranged between I 9 and 44 years. They were paralysed as a result of fracture or fracture dislocations of their cervical vertebrae between two and eighteen months previously. Further clinical details are given in Table I.

Methods. Hand and forearm blood flows were measured by means of waterfilled venous occlusions plethysmographs. The water in the plethysmographs was kept between $30^{\circ}-32^{\circ} \mathrm{C}$. and $34^{\circ}-36^{\circ} \mathrm{C}$. respectively. The technique of Barcroft and Swan (1953) was followed closely.

The heart rate was recorded in some of the experiments on an Ediswan Electroencephalograph machine.

TABLE I

Clinical Details

\begin{tabular}{|c|c|c|c|}
\hline Name & Age & Complete Transverse Spinal Cord Syndrome & Time Since \\
\hline $\begin{array}{l}\text { J. T. } \\
\text { J. Mc. } \\
\text { R. P. } \\
\text { P. O. D. } \\
\text { N. M. } \\
\text { K. J. P. } \\
\text { R. W. } \\
\text { S. G. I. }\end{array}$ & $\begin{array}{l}42 \\
37 \\
44 \\
33 \\
26 \\
21 \\
19 \\
42\end{array}$ & $\begin{array}{l}\text { Below C6 due to fracture dislocation } \mathrm{C}_{5} / 6 \\
\text { Below C6 due to fracture dislocation } \mathrm{C}_{5} / 6 \\
\text { Below C6 due to fracture } \mathrm{C}_{5} \\
\text { Below } \mathrm{C}_{7} \text { due to fracture } \mathrm{C}_{5}, 6 \text { and } 7 \\
\text { Below } \mathrm{C}_{7} \text { due to fracture dislocation } \mathrm{C}_{7} \\
\text { Below } \mathrm{T}_{2} \text { due to fracture dislocation } \mathrm{C}_{5} / 6 \\
\text { Below } \mathrm{T}_{2} \text { due to fracture } \mathrm{C} \\
\text { Below } \mathrm{T}_{3} \text { due to fracture dislocation } \mathrm{C} 6 / 7\end{array}$ & $\begin{array}{l}\text { IO months } \\
2 \text { months } \\
\text { I } 8 \text { months } \\
8 \text { months } \\
\text { I0 months } \\
\text { I9 months } \\
6 \text { months } \\
6 \text { months }\end{array}$ \\
\hline $\begin{array}{l}\text { M. J. D. H. } \\
\text { J. D'A.-E. } \\
\text { J. R. S. }\end{array}$ & $\begin{array}{l}24 \\
25 \\
32\end{array}$ & Normal controls. & \\
\hline
\end{tabular}

The patient was brought to the examination room on his bed, with his head supported by pillows. Hand and forearm blood flows, and the heart rate were recorded for a control period of 30-40 minutes. The Valsalva manœuvre was performed by the subject blowing against a mercury column and holding it at about $40 \mathrm{~mm}$. $\mathrm{Hg}$. for IO seconds.

Indirect heating was achieved by heating the subject's trunk and lower limbs by a heat cradle, which was screened from the patient by a wooden board, covered with silver foil. Oral temperatures were taken at intervals during the indirect heating, with a clinical thermometer for a minimum of three minutes, and the skin temperatures of the forehead, chest, shoulders and elbows were measured with a 'Biatherm Baby' thermistor. The posture of the subject was altered by passively raising the legs, or the legs and lower trunk.

The room temperature was between $18^{\circ}$ and $24^{\circ} \mathrm{C}$. All the patients, except R. P., were examined on at least two different occasions. J. T. was examined six times.

The occurrence of spasms, micturition, sweating or complaints of headache by the patient were carefully noted, since it is known (Guttmann \& Whitteridge, 1947; Gilliatt et al., 1947; Cunningham et al., 1953), that these symptoms can be associated with marked changes in the hand and forearm blood flows in the spinal man. 
Results. For the purpose of description the results obtained in the five patients with complete transverse spinal cord lesions above the sympathetic outflow will be stressed since in these patients the blood vessels in the forearm and hand were deprived of all central control from the brain. The remaining three patients with a little sensory sparing of light touch to the third thoracic dermatome behaved in exactly the same manner as the five patients with complete lesions, suggesting that they too had a complete interruption of the central sympathetic control of the blood vessels in their hands and forearms.

The Response to the Valsalva Manœuvre. During the Valsalva manœuvre in a normal subject, the raised intrathoracic pressure prevents blood entering the heart. This decrease in the filling pressure leads to a decreased stroke output and a fall in the arterial pressure. Reflex vasoconstriction occurs in the forearm blood vessels which persists for up to a minute after the release of the intrathoracic pressure.

Figure I shows the plethysmograph tracings in a normal subject J. D'A.-E.; the time in seconds is horizontal. The vertical deflection shows the volume increase when the cuffs are applied, thus the degree of steepness of the slope is proportional to the blood flow. The two slopes prior to the Valsalva manœuvre are quite steady and are steeper than the slopes immediately after the Valsalva manœuvre, but over the ensuing minute the slopes gradually return to normal. This indicates that there is a decreased blood flow in the forearm during this time, and it has been shown (Sharpey-Schafer, 1953) that this is due to reflex vasoconstriction of the forearm blood vessels.

Figure 2 shows similar slopes obtained from J. T., a male aged 42 with a

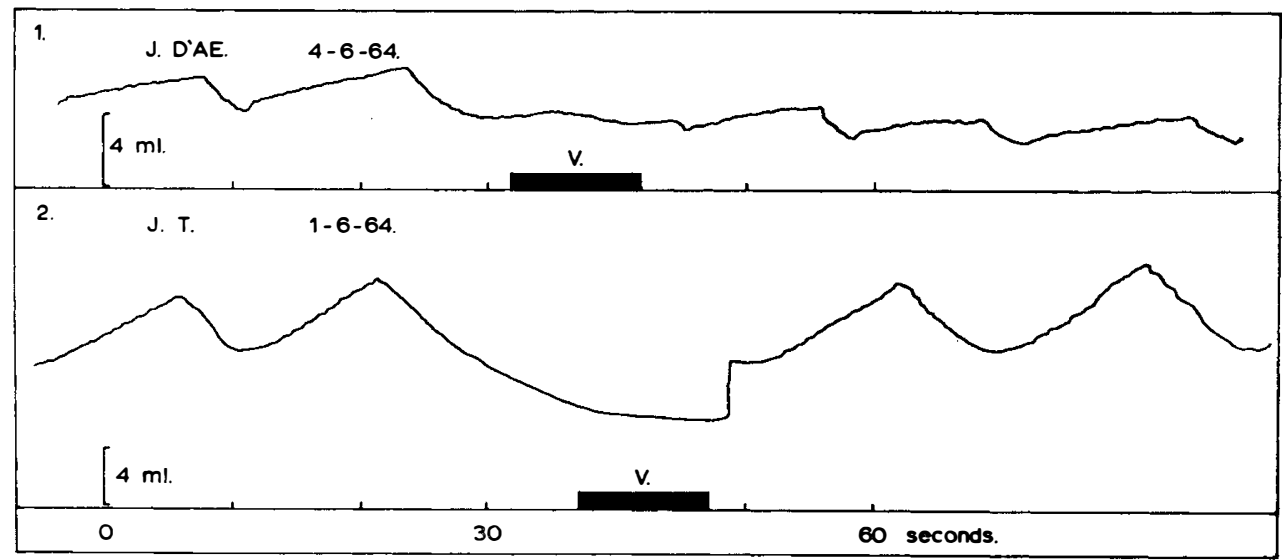

FIG. I

The curve is the right forearm blood flow of a normal subject, J. D'A.-E. The upward deflection is proportionate to the increase in the volume of the forearm when the venous cuff is applied. Time in seconds is marked horizontally. Figure shows the effect of the Valsalva manœuvre, $\mathrm{V}$, resulting in constriction of the forearm blood vessels with a gradual return to normal over the ensuing minute.

FIG. 2

The curve is the right forearm blood flow of J. T., a tetraplegic patient with a complete lesion below C6. Figure shows no change in the blood flow following the Valsalva manœuvre. 
complete lesion below C6 as a result of a car accident Io months previously. There had been no recovery of any kind. The slopes immediately following the Valsalva manœuvre are just as steep as those before, indicating that the blood flow had at once returned to normal, and that there was no persistent vasoconstriction with a gradual return to normal as in Figure $I$.

In Figure 3, again on J. T., the slopes have been converted conventionally into forearm blood flows $\mathrm{ml}$. per $100 \mathrm{ml}$. of tissue per minute expressed vertically, plotted against time in minutes horizontally. There is no sustained fall in the forearm blood flow with a gradual return to normal after the Valsalva manœuvre.

The heart rate counted over Io-second intervals is

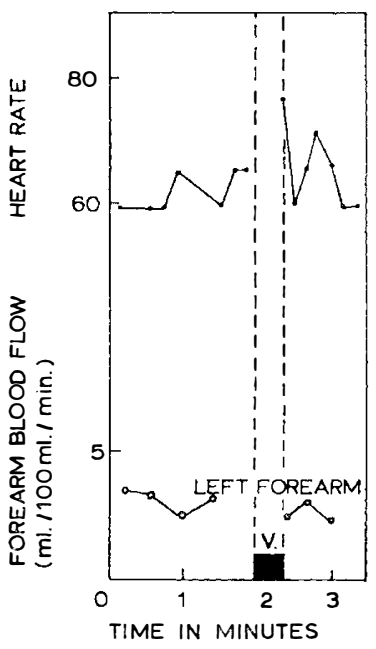

FIG. 3

The effect of the Valsalva manœuvre on the left forearm blood flow and the heart rate in J. T. (a C6 tetraplegic). At the termination of the Valsalva, there is a small fall in the forearm blood flow, but this is not sustained and there is no fall in the heart rate below the resting level. plotted above the forearm blood flows. There is an initial tachycardia at the cessation of the manœuvre, but no sustained bradycardia over the ensuing minute. This is again in contrast to the normal heart rate changes following the Valsalva when a bradycardia is found.

Figure 4 shows similar results in R. P., who had also sustained a complete lesion below C6 some I8 months previously. In neither the left- nor right-hand tracings is there a significant change in the forearm blood flows or the heart rate following the Valsalva manœuvre.

While it is easy to demonstrate a fall in blood flow when there is little resting vasoconstrictor tone and the resting blood flow is high, it can be difficult to demonstrate a fall in blood flow when the resting vasoconstrictor tone is high and the resting blood flow is low. Such a situation pertains in a recumbent subject. Roddie et al. (1958), have pointed out that if the subject's legs are raised, vasoconstrictor tone can be reduced, and the fall in blood flow following the Valsalva will be much more dramatic. Figure 5 shows the effect of increasing the forearm blood flow in $\mathrm{J}$. T. by raising the lower limbs and then performing the Valsalva manœuvre. It confirms that there is still no reduction in forearm blood flow following the Valsalva manœuvre, although there was a fall in the blood flow when the legs were returned to the horizontal position.

The results of the Valsalva manœuvre are given in Table II. Only one of the subjects, J. Mc., was unable to perform the test; he was the most recently injured (two months before the examination). The first column shows the three blood flows before the Valsalva and the second column the three blood flows immediately after the termination of the manœuvre, the duration of these three flows being altogether about a minute. The heart rate counted over Io-second intervals for the half-minute immediately before the manœuvre and the half-minute subsequently are expressed in the last two columns.

All the seven patients behaved in the same way. There was no significant change in the blood flows following the Valsalva manœuvre. Some of the initial flows following the manœuvre were lower than those immediately preceding the 


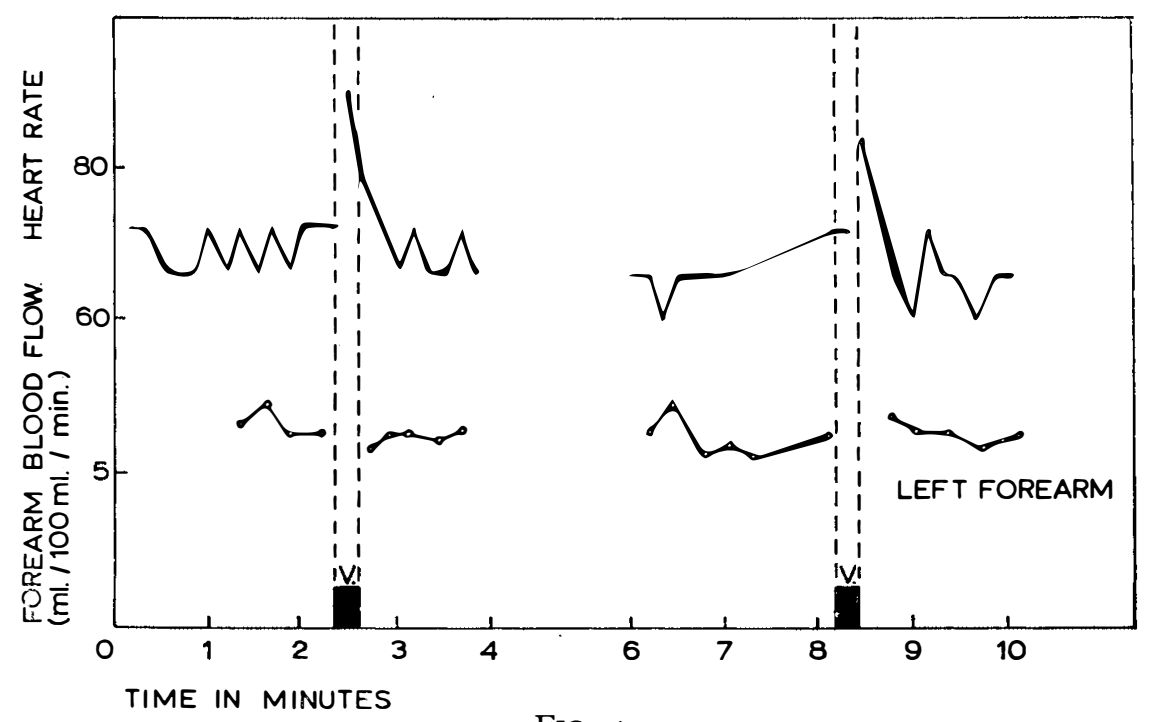

FIG. 4

The effect of the Valsalva on the left forearm blood flows and heart rate in R. P. (a C6 tetraplegic). There is no significant fall in blood flow or heart rate in either tracing.

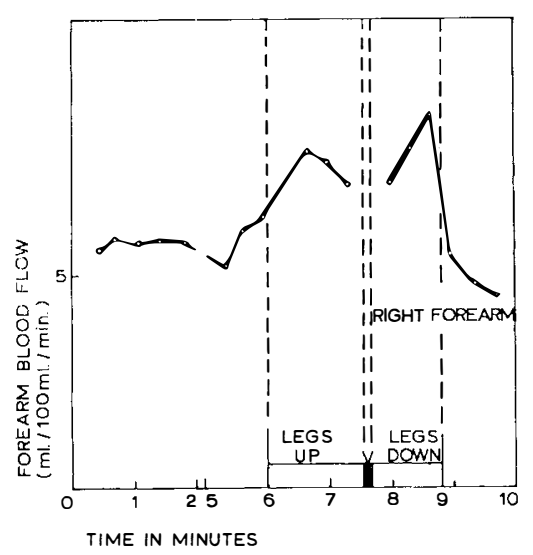

FIG. 5

The effect of the Valsalva on the right forearm blood flow of J. T. (a C6 tetraplegic) when it has been raised by elevating the lower limbs. There is no fall following the Valsalva although the blood flow did fall when the legs were returned to the horizontal.

manœuvre: R. P. I and 2, N. M. I and 2, R. W. 2 and 3, S. G. I. 3, but in other tests on the same patients some of the flows were higher: R. P. 3, S. G. I. I and 2, and there was no consistent pattern of an initial sharp fall in the blood flow with a slow return to normal over the ensuing 4 flows that the normal showed. There was also no accompanying bradycardia.

The Response to Indirect Heating of the Body. The vasodilation which occurs in the hands of normal people in response to heating the trunk and lower limbs is reflex in nature. It is probably initiated in the central nervous system, 
TABLE II

Response to the Valsalva

(Forearm Blood Flows ml./ Io0 ml. of Tissue)

\begin{tabular}{|c|c|c|c|c|c|c|c|c|c|c|c|c|}
\hline \multirow{2}{*}{ Name } & \multirow{2}{*}{\multicolumn{3}{|c|}{$\begin{array}{c}\text { Before } \\
\text { Valsalva }\end{array}$}} & \multirow{2}{*}{\multicolumn{3}{|c|}{$\begin{array}{c}\text { After } \\
\text { Valsalva }\end{array}$}} & \multicolumn{6}{|c|}{ Heart rate counted over Io sec. } \\
\hline & & & & & & & & Befor & & & After & \\
\hline J. T. & $\begin{array}{l}3 \cdot 5 \\
3 \cdot 5\end{array}$ & $\begin{array}{l}3.5 \\
2.5\end{array}$ & $\begin{array}{l}3 \\
3 \cdot 5\end{array}$ & $\begin{array}{l}3 \cdot 2 \\
2 \cdot 5\end{array}$ & $\begin{array}{l}3 \cdot 2 \\
3 \cdot 2\end{array}$ & $\begin{array}{l}4 \cdot 3 \\
2 \cdot 5\end{array}$ & $\begin{array}{l}60 \\
60\end{array}$ & $\begin{array}{l}66 \\
66\end{array}$ & $\begin{array}{l}60 \\
66\end{array}$ & $\begin{array}{l}78 \\
78\end{array}$ & $\begin{array}{l}66 \\
60\end{array}$ & $\begin{array}{l}66 \\
66\end{array}$ \\
\hline J. Mc. & Cou & ld no & per & $n$ the & test & & & & & & & \\
\hline R. P. & $\begin{array}{l}6 \cdot 7 \\
7 \cdot 5 \\
6\end{array}$ & $\begin{array}{l}6 \cdot 5 \\
6 \cdot 5 \\
5 \cdot 5\end{array}$ & $\begin{array}{l}6 \\
6 \cdot 5 \\
6 \cdot 3\end{array}$ & $\begin{array}{l}5 \\
6 \\
7\end{array}$ & $\begin{array}{l}6 \\
6 \cdot 5 \\
6 \cdot 5\end{array}$ & $\begin{array}{l}5 \cdot 5 \\
6 \cdot 5 \\
6 \cdot 3\end{array}$ & $\begin{array}{l}66 \\
72\end{array}$ & $\begin{array}{l}66 \\
72 \\
72\end{array}$ & $\begin{array}{l}72 \\
72\end{array}$ & $\begin{array}{l}84 \\
78 \\
84\end{array}$ & $\begin{array}{l}84 \\
72 \\
72\end{array}$ & $\begin{array}{l}77 \\
66 \\
66\end{array}$ \\
\hline P. O’D. & $\begin{array}{l}6 \\
5 \cdot 5 \\
6\end{array}$ & $\begin{array}{l}5 \cdot 5 \\
6 \\
6\end{array}$ & $\begin{array}{l}5 \cdot 5 \\
5 \cdot 5 \\
6\end{array}$ & $\begin{array}{l}4 \\
4 \cdot 5 \\
5 \cdot 5\end{array}$ & $\begin{array}{l}5 \cdot 5 \\
5 \cdot 5 \\
5 \cdot 5\end{array}$ & $\begin{array}{l}5 \cdot 2 \\
5 \cdot 2 \\
5 \cdot 8\end{array}$ & $\begin{array}{l}84 \\
72 \\
78\end{array}$ & $\begin{array}{l}90 \\
78 \\
78\end{array}$ & $\begin{array}{l}84 \\
72 \\
72\end{array}$ & $\begin{array}{r}\text { I } 18 \\
90 \\
120\end{array}$ & $\begin{array}{l}84 \\
72 \\
96\end{array}$ & $\begin{array}{l}78 \\
78 \\
90\end{array}$ \\
\hline N. M. & $\begin{array}{l}4 \\
4.5\end{array}$ & $\begin{array}{l}5 \\
5 \cdot 5\end{array}$ & $\begin{array}{l}5 \\
5 \cdot 5\end{array}$ & $\begin{array}{l}4 \cdot 5 \\
4\end{array}$ & $\begin{array}{l}4 \\
4\end{array}$ & $\begin{array}{l}4 \cdot 5 \\
5 \cdot 2\end{array}$ & $\begin{array}{l}60 \\
78\end{array}$ & $\begin{array}{l}60 \\
84\end{array}$ & $\begin{array}{l}72 \\
72\end{array}$ & $\begin{array}{l}78 \\
96\end{array}$ & $\begin{array}{l}78 \\
90\end{array}$ & $\begin{array}{l}66 \\
78\end{array}$ \\
\hline K. J. P. & $\begin{array}{l}3 \\
3 \cdot 7 \\
2 \cdot 2\end{array}$ & $\begin{array}{l}3.2 \\
3.5 \\
2.7\end{array}$ & $\begin{array}{l}2 \cdot 5 \\
2 \cdot 4 \\
3\end{array}$ & $\begin{array}{l}2 \cdot 5 \\
3 \\
2 \cdot 6\end{array}$ & $\begin{array}{l}3 \cdot 2 \\
3 \\
3\end{array}$ & $\begin{array}{l}3 \cdot 2 \\
3 \cdot 2 \\
3\end{array}$ & $\begin{array}{l}48 \\
54 \\
54\end{array}$ & $\begin{array}{l}60 \\
66 \\
54\end{array}$ & $\begin{array}{l}60 \\
54 \\
54\end{array}$ & $\begin{array}{l}60 \\
60 \\
54\end{array}$ & $\begin{array}{l}60 \\
66 \\
60\end{array}$ & $\begin{array}{l}54 \\
60 \\
54\end{array}$ \\
\hline R. W. & $\begin{array}{l}6 \cdot 2 \\
4 \cdot 5 \\
5 \cdot 5\end{array}$ & $\begin{array}{l}5 \cdot 2 \\
5 \cdot 5 \\
5 \cdot 3\end{array}$ & $\begin{array}{l}4 \cdot 5 \\
6 \\
7\end{array}$ & $\begin{array}{l}5 \cdot 6 \\
5 \\
4 \cdot 5\end{array}$ & $\begin{array}{l}5 \cdot 8 \\
5 \cdot 2 \\
6 \cdot 5\end{array}$ & $\begin{array}{l}6 \cdot 2 \\
5 \cdot 7 \\
6 \cdot 5\end{array}$ & $\begin{array}{l}54 \\
54 \\
54\end{array}$ & $\begin{array}{l}54 \\
60 \\
54\end{array}$ & $\begin{array}{l}66 \\
60 \\
60\end{array}$ & $\begin{array}{l}66 \\
66 \\
60\end{array}$ & $\begin{array}{l}60 \\
60 \\
60\end{array}$ & $\begin{array}{l}60 \\
54 \\
54\end{array}$ \\
\hline S. G. I. & $\begin{array}{l}3 \\
4 \\
4 \cdot 5\end{array}$ & $\begin{array}{l}3 \\
3 \cdot 5 \\
5 \cdot 2\end{array}$ & $\begin{array}{l}3 \cdot 3 \\
4 \\
5\end{array}$ & $\begin{array}{l}7 \cdot 5 \\
5 \cdot 5 \\
4 \cdot 3\end{array}$ & $\begin{array}{l}3 \cdot 5 \\
4 \cdot 5 \\
3 \cdot 3\end{array}$ & $\begin{array}{l}3 \cdot 2 \\
5 \cdot 2 \\
3.6\end{array}$ & $\begin{array}{l}54 \\
54 \\
60\end{array}$ & $\begin{array}{l}54 \\
54 \\
54\end{array}$ & $\begin{array}{l}60 \\
60 \\
54\end{array}$ & $\begin{array}{l}72 \\
60 \\
60\end{array}$ & $\begin{array}{l}66 \\
60 \\
60\end{array}$ & $\begin{array}{l}60 \\
60 \\
54\end{array}$ \\
\hline
\end{tabular}

and mediated via spinal cord and sympathetic efferents, the stimulus being a rise in skin and blood temperatures. Figure 6 shows forearm and hand blood flows in a normal subject recorded simultaneously with the corresponding oral and forehead temperatures. Initially the subject lay supine and naked for 20 minutes on a bed. Resting blood flows and temperatures were taken, then the heat cradle was turned on. The blood flows in the left hand began to increase rapidly within 5 minutes of heating from about $5 \mathrm{ml}$./ $100 \mathrm{ml}$. of tissue per minute to Io and eventually nearly $20 \mathrm{ml}$./100 $\mathrm{ml}$. of tissue per minute. During the corresponding time there was a small increase of the right forearm blood flow from $2 \frac{1}{2}$ to $4 \mathrm{ml}$./ $100 \mathrm{ml}$. of tissue per minute. The oral temperature dropped a little while the forehead temperature rose. In contrast to these findings was the response to indirect heating in the tetraplegic J. T. as shown in Figure 7. Following a much longer period of 


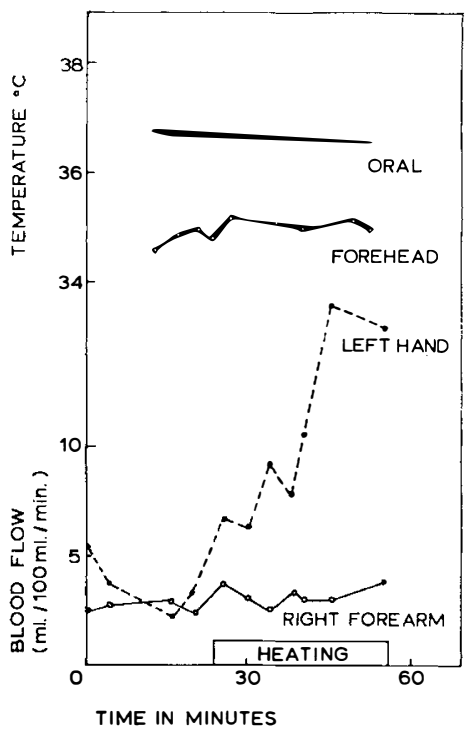

FIG. 6

Right forearm and left-hand blood flows before and during indirect body heating with oral and forehead temperatures in a normal subject, M. J., D. H. There is a rapid increase in the hand blood flows immediately the heating commenced with much less increase in the forearm blood flows. There is no increase in the oral temperature.

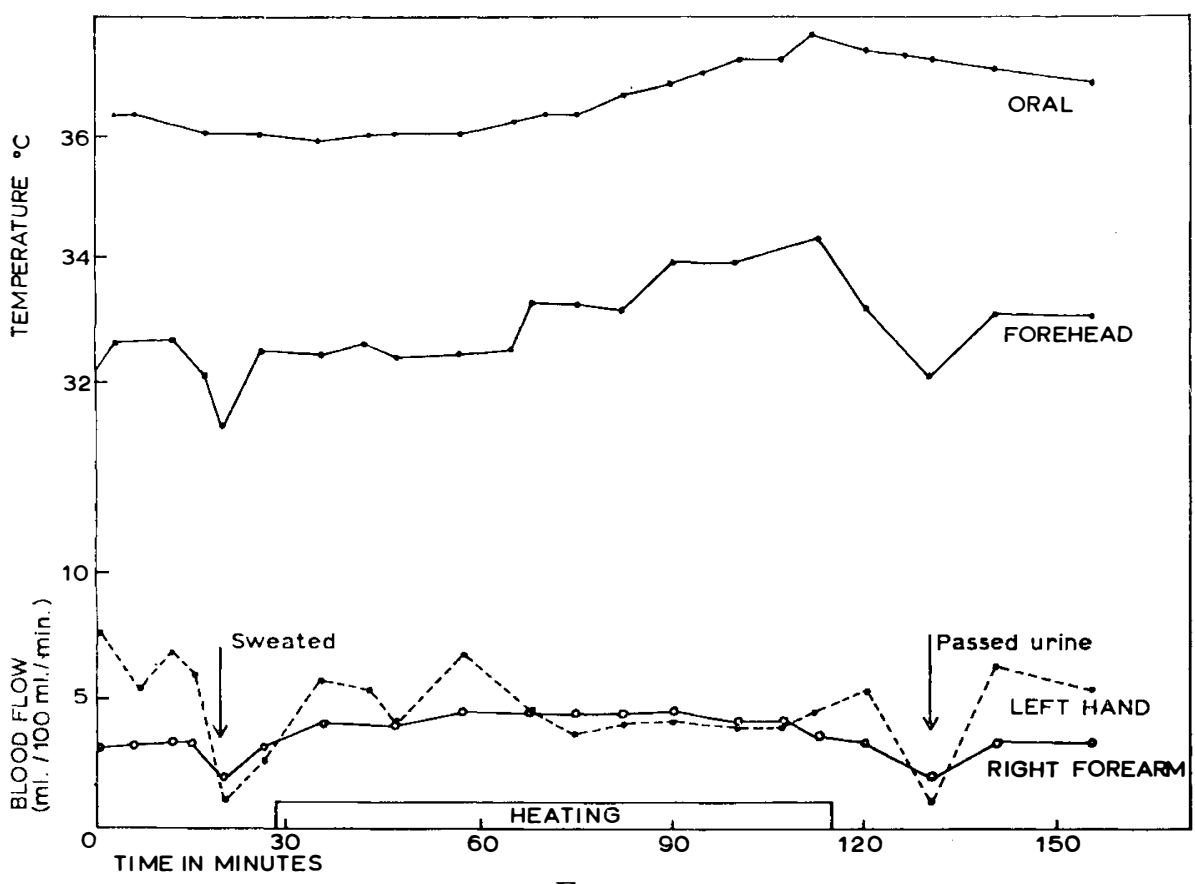

Fig. 7

Right forearm and left-hand blood flows before and during indirect body heating with oral and forehead temperatures in J. T. (a C6 tetraplegic). There is no increase in the hand blood flow and only a slight increase in the forearm blood flow despite almost a two-degree rise in oral temperature. There is a sharp fall in the forehead temperature and the hand and forearm blood flows at 20 and I25 minutes that accompanied bladder distension. 


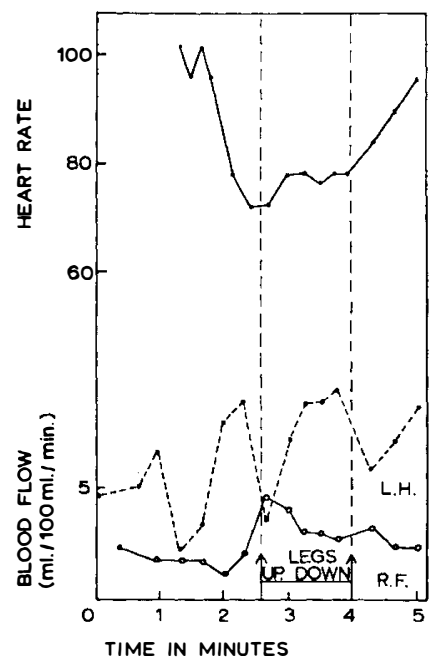

FIG. 8

The effect of raising the lower limbs passively of $\mathrm{J}$. T. (a C6 tetraplegic) on the left hand (L. H.) and right forearm (R. F.) blood flows and on the heart rate. There is a rise in the forearm blood flow on elevation of the legs which falls on lowering the legs. There is no consistent change in the hand blood flow. There appears to be some slowing of the heart rate during the manœuvre, with a return to its original rate at the termination of the manœuvres.

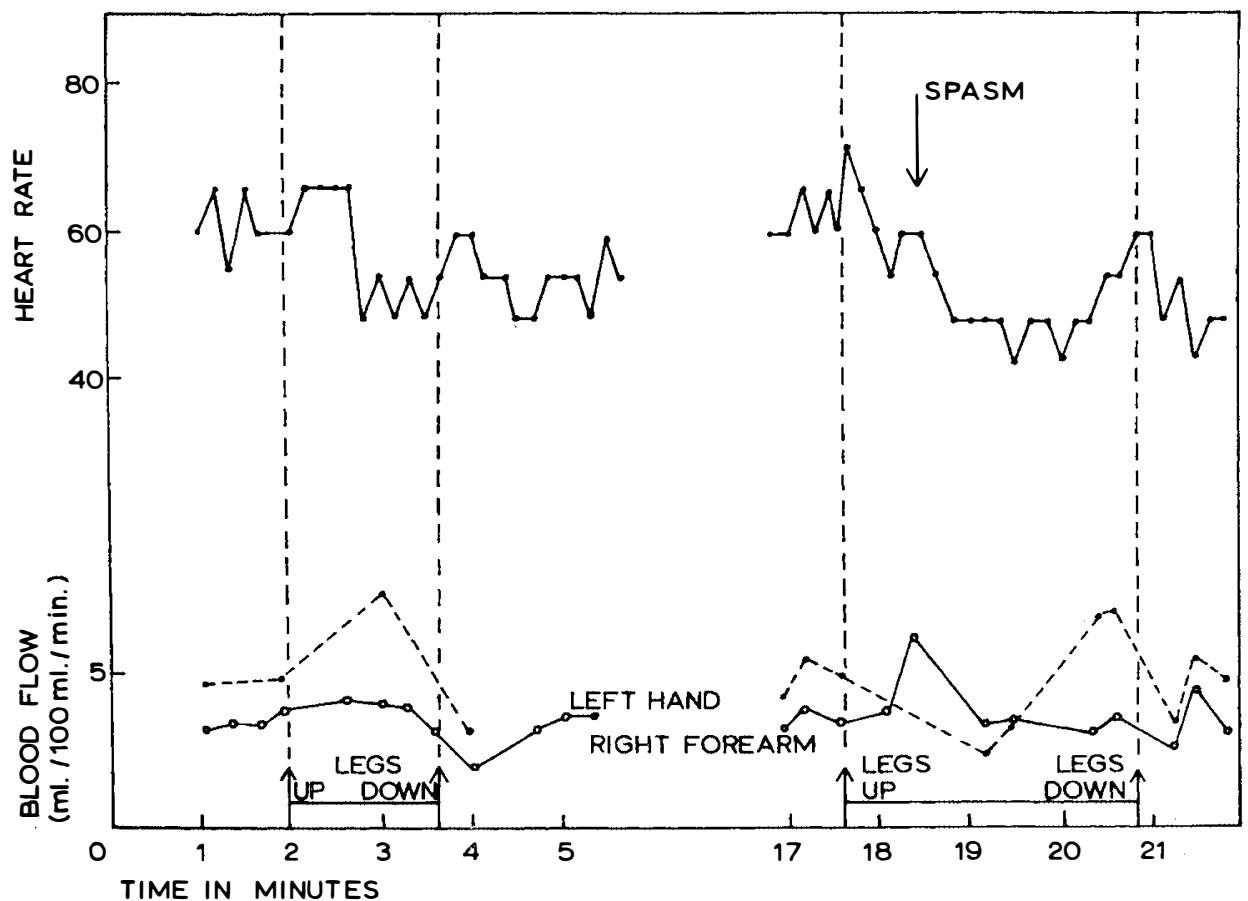

FIG. 9

The effect of raising the lower limbs passively in J. Mc. C. (a C6 tetraplegic) on the lefthand and right forearm blood flow and the heart rate. In the left-hand tracing there is a small but consistent increase of the forearm flow on elevation of the legs which returns to normal when the legs are lowered. This is accompanied by a bradycardia. In the righthand tracing there is a spasm which affects the forearm blood flows and makes interpretation difficult. 
heating under identical conditions there was no increase in the hand blood flow and only a little increase in the forearm blood flow. The forehead temperature rose nearly to $2^{\circ} \mathrm{C}$. and the oral temperature $I^{\circ} \mathrm{C}$., a more than adequate stimulus to ensure reflex dilatation of the hand blood vessels.

The sharp drop in the forehead temperature and in the forearm and hand blood flows at 25 and 125 minutes illustrates the effect of detrusor activity of the bladder upon the autonomic nervous system in producing vasoconstriction in the paralysed areas. All other patients studied behaved in the same way, with a failure to increase their hand blood flows in response to indirect heating.

The response in these patients to the Valsalva manœuvre and to indirect heating confirms the clinical diagnosis that all these subjects had complete transverse spinal cord syndromes above the sympathetic outflow.

Effect of Raising the Lower Limbs Passively. The normal vascular response in muscle to raising the lower limbs passively depends upon shifting blood from the legs and results in a dilatation of forearm blood vessels, usually accompanied by a tachycardia. Roddie et al. (1958) have shown that the changes are not related to changes in arterial or mean pulse pressure but are due to reflex changes probably from low pressure receptors in the chest.

Figure 8 shows the effect of raising the lower limbs of J. T. passively. The resting flow in his forearm is quite steady at about $2 \mathrm{ml}$. per $100 \mathrm{ml}$. of tissue and this rises with elevation of his legs to nearly $5 \mathrm{ml}$. per $100 \mathrm{ml}$. of tissue; the flow subsides to a lower level then the initially high transient, but the flow is still higher than normal until the legs are lowered to the horizontal again. The hand blood flows are much more irregular and show no consistent pattern. The heart rate slows during the elevation of the legs in this figure, and returns to its resting level immediately the legs are returned to the horizontal position.

Figure 9 shows the effect of passive elevation of the lower limbs in J. Mc., another lesion below C6. In the left-hand tracing, although the rise in the forearm flow is much smaller it is quite consistent and terminates when the legs are restored to the horizontal position. The right-hand tracing is complicated by the development of a flexor spasm on manipulation of the lower limbs. But accompanying both of the elevations of the legs in Figure 9 there is a significant and sustained bradycardia once the initial transient tachycardia following the initial manipulation of the legs has subsided. In this case the initial heart rate was much slower than in Figure 8. The results are presented in Table III, the first column being the average of 3 blood flows before elevation of the lower limbs, the next column the average of 3 flows while the limbs were elevated. In all patients the blood flow in the forearm increased upon passive elevation of the lower limbs on at least one occasion.

The accompanying changes in the heart rate are of great interest, all the patients showed an initial tachycardia during the first half-minute during and after the legs were being elevated, but the subsequent course was more variable and the majority of the patients developed a bradycardia like the cases illustrated in Figures 8-9. This response is in contrast to that of normal subjects who react with tachycardia. 


\section{TABLE III}

Response to Elevation of the Legs

\begin{tabular}{|c|c|c|}
\hline Name & Before & During \\
\hline J. T. & $\begin{array}{l}7 \cdot 5 \\
2 \cdot 5 \\
2 \cdot 6 \\
4 \\
\text { I.4 } \\
\text { I.4 }\end{array}$ & $\begin{array}{l}8 \cdot 3 \\
3 \cdot 7 \\
3 \cdot 4 \\
3 \cdot 9 \\
3 \cdot 4 \\
2 \cdot 6\end{array}$ \\
\hline J. Mc. & $3 \cdot 2$ & $3 \cdot 8$ \\
\hline R. P. & $\begin{array}{l}4 \cdot 7 \\
6\end{array}$ & $\begin{array}{l}6 \cdot 3 \\
7 \cdot 1\end{array}$ \\
\hline P. O. D. & $\begin{array}{l}6 \cdot 5 \\
4 \cdot 8\end{array}$ & $\begin{array}{l}9 \\
4 \cdot 3\end{array}$ \\
\hline K. J. P. & $\begin{array}{l}4 \cdot 6 \\
3 \cdot I \\
4 \cdot 2\end{array}$ & $\begin{array}{l}6 \cdot 9 \\
6 \\
5 \cdot 8\end{array}$ \\
\hline R. W. & $\begin{array}{l}4 \cdot 2 \\
2 \cdot 5 \\
2 \cdot I\end{array}$ & $\begin{array}{l}6 \cdot I \\
3 \cdot 3 \\
4 \cdot 4\end{array}$ \\
\hline
\end{tabular}

\section{DISCUSSION}

The negative responses in the tetraplegic patient to the Valsalva manœuvre and indirect heating taken in conjunction with the clinical examination indicate that these patients had a complete interruption in the continuity of their spinal cords. These findings are in accordance with those described by Cooper et al. (1957) on heating tetraplegic patients and measuring the blood flow in their feet and by Watson (1962) on performing the Valsalva in tetraplegic patients

The interesting results are that in this group of patients who appear to have a complete spinal cord lesion, passive elevation of the lower limbs elicits a normal response of vasodilatation in the forearm muscles, and returning the lower limbs to the horizontal position restores the blood flow to normal. These results would indicate that this is a spinal reflex.

Roddie et al. (1958), have shown that in normal subjects this reflex is initiated by a shift of blood from the lower limbs which stimulates low-pressure receptors situated in the chest.

The elicitation of bradycardia in the majority of these subjects would serve as confirmatory evidence, since this response of vasodilatation in the peripheral vascular bed and bradycardia has been described on the stimulation of these receptors in animals (Keele \& Neil, 196I). Presumably in normal subjects the response of the heart to an increased venous return caused by elevation of the lower 
limbs is a balance between the low-pressure receptors tending to slow the heart and influences from higher centres accelerating the heart. On these patients the removal of the influences from higher centres (by the complete cord lesion) unmasks the full response of the low pressure receptors. Vascular reflexes of the skin at a spinal level have been described by Guttmann and Whitteridge (1947) and by Gilliatt et al. (1947), and it is not surprising that further reflexes that are more directly concerned with the regulations of the blood pressure should be found since tetraplegic patients are able to adjust themselves in time to sitting or standing without fainting.

\section{SUMMARY}

Three normal controls and eight tetraplegic patients with complete transverse spinal cord syndromes between $\mathrm{C} 6$ and $\mathrm{T}_{3}$ were studied. Five of the patients had complete lesions above C8. Hand and forearm blood flows were measured with water filled venous occlusion plethysmographs maintained at $30^{\circ}-32^{\circ} \mathrm{C}$. and $34^{\circ}-36^{\circ} \mathrm{C}$. respectively. Skin temperature and heart rate were also recorded.

The effects of the Valsalva manœuvre, passive elevation of the legs and indirect heating were studied. It was found that the blood flow of the tetraplegic patients did not increase in response to indirect heating which raised the oral temperature nearly two degrees centigrade, and failed to alter following the Valsalva manœuvre. In contrast, there was an increase in the forearm blood flow in response to passive elevation of the legs which returned to normal when the legs were restored to the horizontal position. This was accompanied in some cases by a bradycardia. It was concluded that this was a spinal reflex.

The significance of these findings is discussed in relation to the central and peripheral control of the blood vessels, and the pathways involved.

\section{ACKNOWLEDGEMENTS}

I wish to thank Dr. L. Guttmann for his encouragement, advice and help throughout the preparation of this work.

I would also like to thank Professor H. Barcroft, who donated the plethysmograph casings and Professor E. Neil who provided the Electroencephalograph machine.

This work was carried out with the aid of Grants from the Polio Research Fund and the Medical Research Council.

\section{RÉSUMÉ}

Trois contrôles normaux et huit tétraplégiques avec des lésions complètes entre C6 et $\mathrm{T}_{3}$ ont été étudiès. Cinq de ceux-ci avaient des lésions complètes au-dessus de C8. Le volume circulatoire a été mesuré, au niveau de l'avant bras et de la main, grâce à un plethsymographe rempli d'eau à une temperature respectivement de $30-32^{\circ} \mathrm{C}$. et $34-36^{\circ} \mathrm{C}$.

La température cutanée et le rythme cardiaque ont été également étudiés. Les effets de la manœuvre de Valsalva, l'élévation passive des membres inferieurs, et le réchauffement indirect ont été étudiés.

Il a été trouvé que le volume circulatoire des tétraplégiques n'augmentait pas en reponse a un réchauffement indirect suffisant pour augmenter la temperature bucale de deux degrés centigrades, et ne montra pas de difference après la manœuvre de Valsalva. Au contraire, le volume circulatoire augmenta à la suite de l'élévation passive des membres inférieurs et redevint normal quand ceux-ci furent de nouveau placés horizontalement. Ces changements furent dans quelques cas accompagnés de bradycardie. Il a été conclu qu'on se trouve en presence d'un reflexe spinal. Ces resultats ont été étudiés en relation avec le contrôle central et peripherique des vaisseaux sanguins et leurs cheminement. 


\title{
ZUSAMMENFASSUNG
}

3 normale Versuchspersonen und 8 Tetraplegiker mit kompletten Querschnittsläsionen zwischen $\mathrm{C} 6$ und $\mathrm{T} 3 \mathrm{w}$ wrden untersucht.

5 Patienten hatten komplette Lähmungen oberhalb C8. Durchblutung in der Hand und dem Unterarm wurde gemessen mit wassergefüllten Plethysmographen bei einer konstanten Temperatur von entweder $30^{\circ}-32^{\circ} \mathrm{C}$. oder $34^{\circ}-36^{\circ} \mathrm{C}$.

Hauttemperatur und Herzrhythmus wurden ebenfalls kontrolliert. Der Effekt des Valsalva Manövers, passiver Hochlagerung der Beine und indirekter Erwärmung wurde untersucht.

Wir fanden, dass beim Tetraplegiker die Durchblutung nicht ansteigt, wenn man den Patienten indirekt erwärmt-mit einem Temperaturanstieg im Munde um $2^{\circ} \mathrm{C}$. - oder als Konsequenz des Valsalva Manövers.

Im Gegensatz zu diesem negativen Resultat fanden wir einen Anstieg in der Durchblutung des Unterarms, wenn die Beine hochgelagert wurden. Sobald sie wieder horizontal gelagert wurden, kehrte die Durchblutung zum Ausgangspunkt zurück. Dies war in einigen Fällen von Bradycardie begleitet. Wir deuteten dies als einen spinalen Reflex.

Die Bedeutung dieser Resultate für die Kenntnis der zentralen und peripheren Steuerung der Gefässe und der beteiligten Leitungsbahnen wird erörtert.

\section{REFERENCES}

Barcroft, H. \& Swann, H. J. C. (1953). Sympathetic Control of Human Blood Vessels. London: Arnold.

Cooper, K. E., Ferres, H. M. \& Guttmann, L. (1957). F. Physiol. 136, 577.

Cunningham, D. J. C., Guttmann, L., Whitteridge, D. \& Wyndham, C. H. (I953). F. Physiol. I2I, 58I.

Gilliatt, R. W., Guttmann, L. \& Whitteridge, D. (1947). F. Physiol. 107, 67.

GutTMANN, L. \& WhitTeridge, D. (1947). Brain, 70, 36I.

KeEle, C. A. \& NeIl, E. (I96I). Samson Wright's Applied Physiology. London: Oxford University Press.

Roddie, I. C., Shepherd, J. T. \& Whelan, R. F. (1958). Circulat. Res. 6, 232.

SharpeY-Schafer, E. P. (1953). F. Physiol. 122, 35 I.

SHARPEY-SCHAFER, E. P. (I956). F. Physiol. 134, I.

Shepherd, J. T. (1963). Physiology of the Circulation in Human Limbs in Health and Disease. Philadelphia and London: Saunders.

Watson, W. E. (1962). F. Neurol. Neurosurg. Psychiat. 25, I9.

\section{RADIO-ISOTOPE NEPHROGRAPHIC STUDIES IN PARAPLEGICS}

\author{
By V. Paeslack, M.D., F. Roehl, M.D. and K. zum Winkel, M.D. \\ Department of Orthopedics (Director: Professor Dr. K. Lindemann) and the \\ Czerny Hospital for Radiotherapy (Director: Professor F. Becker), \\ University of Heidelberg
}

'IT should always be remembered that the bladder is a social convenience, but the kidneys are essential for life.'

In this statement of Davis the situation of the paraplegic is also defined. Pyelonephritis, uraemia and urosepsis are a threat to the life of every patient, and his prognosis is decided by the renal function. For that reason, regular kidney function tests are as necessary as the careful supervision of the bladder.

This requirement unfortunately is often neglected and is difficult to fulfil. The functions and structure of the kidney are so complex that it is difficult to distinguish which part is involved. For this reason, there is no single method by which adequate function of the whole organ can be measured. We depend upon 